\begin{tabular}{|c|c|c|}
\hline PORT SAID ENGINEERING RESEARCH JOURNAL \\
Faculty of Engineering - Port Said University \\
Volume 17 No. 1 pp: 68:78
\end{tabular}

\title{
Waste Minimization in Infrastructure Projects in Egypt
}

\author{
M.A.E.M Khalil ${ }^{1}$, N-A.M.Hussein ${ }^{2}$, A.S.Eisawy ${ }^{3}$, M.A.Mohamedien $^{4}$
}

\section{ABSTRACT}

Waste is one of the most sophisticated problems which adversely affect the construction sector in Egypt. Substantial amounts of materials have been over consumed in different project stages. Examples of these stages are; design, documentation, procurement, handling, transportation storage, operation and inspection. Improper waste management and lack of concern given for waste minimization leads to excessive wastage of materials. The scope of this study covers the construction companies which possess experience in infrastructure field. Infrastructure projects are huge concerning capital and importance. It also includes big variety of activities which can be considered as a representative to the hole construction industry. This study aims to identify the main factors that cause waste in infrastructure projects in Egypt. It aims also to identify the severity of these factors.

Questionnaire was designed to collect data in order to carry out the objectives of this study. The questionnaire includes 67 main factors causing waste divided into 10 categories representing all project stages. Out of 180 questionnaires distributed, only 51 have been responded. Data has been analyzed using "Statistical Package For Social Science" (SPSS) software. Analysis of data shows that the main causes of material waste are: Delay in taking decision by the project manager, Low technical level of labors, Low level of project manager in managing the work and Poor planning of project layout.

A program was designed using "Visual Basic" to help the project team parties to predict the waste in an infrastructure project. It also help them to make a price bid. The program considers 12 of construction materials where the user define the price and quantity of each material. These construction materials are the most consumed in infrastructure projects. Then, the user answers 99 questions which represent all project characteristics. The program gives the user the probable waste percent for each material and estimated waste quantity. Finally, the program offers some advices in accordance with user answers to minimize waste.

\section{1-INTRODUTION}

The Egyptian construction industry has achieved a significant development. Buildings, roads, bridges, infrastructure and water supply projects were implemented on a large scale in recent years. This progress will attract investments, increase the standard of living and provide different kinds of job opportunities. The establishment of new cities in the wide open spaces of desert will redistribute the overpopulation in Nile delta stripe.

There are several conditions that must be achieved for the project success such as finishing on time, according to specifications and within budget. Several factors could negatively affect the project's success. Due to lack of concern given for these factors, the construction sector in

\footnotetext{
1 Civil Engineering Department, Faculty of engineering, Port Said University, Port Said, Egypt, E-mail: maelmoty11@yahoo.com

2 Assistant professor, Civil Engineering Department, Faculty of engineering, Port Said University, Port Said, Egypt, E-mail: nourallah@gmail.com

${ }^{3}$ Professor, Civil Engineering Department, Faculty of engineering, Ain shams University, Cairo, Egypt, E-mail: tebrconsulting@gmail.com

${ }_{4}^{4}$ Professor, Civil Engineering Department, Faculty of engineering, President of Suez Canal University, E-mail: president_office@suez.edu.eg
}

developing countries is usually suffering from losses. These factors could happen during different project stages like design, documentation, procurement, handling, transportation, storage, operation and inspection.

Many of materials' industries have evolved with the development of construction industry. The construction industry consumes huge amounts of raw materials. There are two main disadvantages of waste. First, it has a very negative financial impact on construction sector as it is one of the serious reasons which cause high prices. Moreover, waste is one of the most environmental polluters but this factor is considered only in developed countries of Europe and United states.

Construction management is no longer an option but a necessity. It contributes strongly to the development of construction industry. Management application on construction projects will contribute in avoiding many problems that lead to losses. Reworking of finished activities, reordering of materials, rent equipment and labor before or after the required time, storing the materials for long time are examples of poor performance which will strongly cause losses. 


\subsection{Background of Research}

Waste is a global phenomenon associated with the progress of the construction sector in any place. Many researches discussed this problem from different points of views. Some researchers discussed the "4R" concept which represent the four methods used for controlling waste; reduce, reuse, recycle and recovery. Reduction or prevention of waste factors was selected by many researchers as the best technique for controlling waste as it try to solve the problem before happening. Other researchers discussed causes of poor performance in construction sector. Several researches discussed each method of those "4R" used for controlling waste separately.

\subsection{Problem Statement}

One of the main reasons that lead to growth of construction sector is reasonable unit price of construction activities. Price analysis consists of two main components, namely direct and indirrec cost. The contractor will consider the waste cost in bid using previous experience in a similar project. For example, if the contractor found from his experience by working in one of the infrastructure projects that waste in pipes is about $15 \%$. As a result, the contractor will raise unit price of pipes by the same percentage. There is another problem caused by the transfer of waste to landfills. Some countries have specific areas as landfill and these spaces will expire with the increase of amount of waste. Some developed countries have focused on the impact of construction waste on the environment. As a result, these countries have to raise taxes on the transfer of waste to landfills.

Finally, the purpose of this research is to identify the main reasons which leads to waste to be avoided and therefore the percentage of waste and price will be reduced. If there aren't any actions to reduce the high value of the waste there will be no control on prices.

\subsection{Objectives of the Study}

The objectives of this work could be drawn as:

(1) To identify the factors that cause waste in construction projects in Egypt,

(2) To determine the severity of these factors and there priority order or rank,

(3) Develop computerized checklist to help project team players to avoid these factors, and

(4) Propose guidelines to project team players to minimize waste.

\subsection{Scope of Study}

This research will focus on investigating waste management techniques in infrastructure projects as a result of increasing size of these projects in egypt in recent years because of its priority as it precedes other civil works. Therefore, this paper aims to focus on determining factors causing waste in this kind of projects.

\section{LITERATURE REVIEW}

\subsection{Definition of Waste}

Construction material wastes refer to materials from construction sites that are unusable for the purpose of construction and have to be discarded for whatever reason (Yahya and Boussabaine, 2006) $^{[1]}$.

Debris is solid waste from construction, remodeling, repair or demolition of buildings, roads or other structures. Examples of debris are: rest of wood, concrete, drywall, masonry, roofing, siding, structural metal, wire, insulation, asphalt, packaging materials related to construction or demolition and other materials applied in construction. ( CRISTIANO,2007) ${ }^{[2]}$.

Construction waste was defined as any material apart from earth materials, which needed to be transported elsewhere from the construction site or used on the site itself other than the intended specific purpose of the project due to damage, excess or non-use or which cannot be used due to non-compliance with the specifications, or which is a by-product of the construction process. (Ekanayake and Ofori, 2004) ${ }^{[3]}$.

\subsection{Waste Measurement}

In united kingdom (Rohit Bhagwat,2008) ${ }^{[4]}$ summarized statistical information about waste which shows that 335 million tones of waste was generated included approximately 100 million tones of minerals waste, and 220 million tones of controlled wastes from households, commerce, and industry which also includes construction and demolition wasted. About $60 \%$ of total waste sent to landfill, $6 \%$ incinerated, $10 \%$ recycled and $22 \%$ treated using various methods. Due to high percent of waste sent to landfill the united kingdom government goes to rise the landfill taxes. This decision was taken as the available landfill sites have very limited life span. The following figure (2-1) shows the rise in landfill taxes from year 1996 to 2009 .

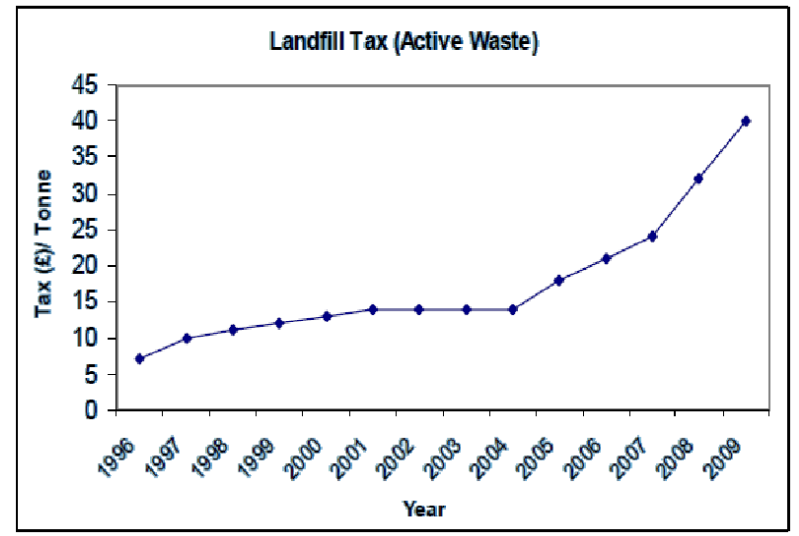

fig. no.(2-1) increase in landfill taxes from year 1996 to 2009 (Rohit Bhagwat,2008) ${ }^{[4]}$ 
The amount of waste in Brazil is between 20 to $30 \%$ of material weight entered a construction site (Pint and Agapyan, 1994) ${ }^{[5]}$. 25\% of materials in construction process waste (Hamassaki and Neto ,1994) ${ }^{[6]}$, $20 \%$ of material entered the site are wasted (Formoso et al., 1994) ${ }^{[7]}$,

(Wong Xiao Wen, 2007) ${ }^{[8]}$ indicated that the construction sector in united stated of America produced 136 million tones of construction and demolition waste. The annual production rate of construction and demolition waste from the whole planet is around 3 billion ton (Mohd Fidaus, 2009) ${ }^{[9]}$

\subsection{Waste Management}

\subsubsection{Waste management hierarchy}

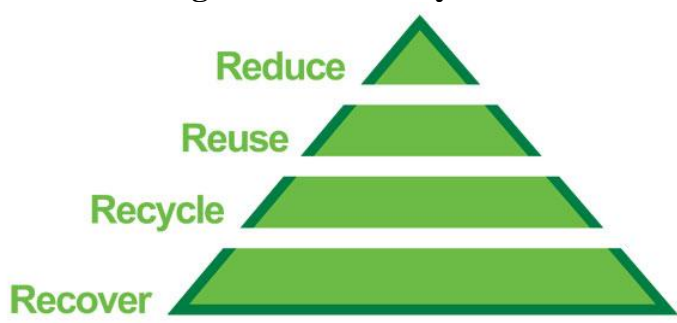

Fig.no.(2-2) Waste management hierarchy,

\section{Reduction:}

Reduction of waste was chosen by many researches as the best strategy to control waste. Reduction of waste at source is very helpful as it try to solve the problem before it becomes complex. Reduction is better than reuse, recycle and recovery as it avoid the generation of waste. It could be the best strategy for countries with minimum financial resource. Reduction could be implemented during design, documentation, handling, storage, supervision and ...etc.

(Wong Xiao Wen,2007) ${ }^{[8]}$ summarized the benefits of waste reduction such; increase profit, increase landfill life, reduce environmental impact, conservation of natural resources, cleaner and safer construction site and improve company image..

\section{Reuse:}

Reuse techniques is defined as re-employment of materials to be reuse in the same application or to be used in lower grade applications in the project. Materials such as wood, earthworks, steel, concrete, masonry, tiles, plasterboard, insulation materials, paints, solvent and carpets can be profitably reused on the construction site (Mohd Fidaus, 2009) ${ }^{[9]}$.

\section{Recycle:}

Concrete, plastic, asphalt and brick are some of main materials which must be utilized in any infrastructure project. Recycling mean these previous waste materials in other different ways such as using the crushed concrete in protection of levee, sub-base, backfilling and foundation material. The main precaution when using recycling is to make the required tests to ensure the quality of recycled materials.

\section{Recovery:}

A recovery technique is a process of generating energy from waste materials that cannot be reduced, reused or recycled. (Mohd Fidaus, 2009) ${ }^{[9]}$. Hauling and disposal costs, the value of recovered materials, and labor costs contribute to whether materials recovery is more or less cost-effective than disposing of materials. Recovery of low value materials may be cost-effective if disposal costs are high and removal and sorting are not labor intensive. The added labor necessary to remove items for reuse may be offset by savings from both the avoided costs of purchasing new materials and avoided disposal costs. (Said Saker,2006) ${ }^{[10]}$.

\section{DATA COLLECTION METHODOLOGY}

There are different ways to collect data such as interviews, books, standards, E-mail survey and questionnaire. This study will use questionnaire to accomplish the aim of this research. Close-ended questions and likert scale can strongly achieve quick and accurate analysis. In likert questions the respondent will be asked to express his agreement or disagreement according to a scale as shown in the following table.

Table no. (3-1) Degrees of agreement

\begin{tabular}{|c|c|}
\hline Least important & 1 \\
\hline Less important & 2 \\
\hline Moderate important & 3 \\
\hline Very important & 4 \\
\hline Most important & 5 \\
\hline
\end{tabular}

The questionnaire consists of three main parts. Part (A) includes information about the respondent company like experience, classification, number of employees and number of projects implemented by the company in the last five years.

In section (B) the respondent is asked to show his company strategy to control waste. Different kinds of waste strategies were listed and the respondent selects the strategy he usually uses in his company.

Section (C) includes 67 factors causing waste. The respondent would state his opinion for each factor according to the previous scale.

\subsection{Pilot test}

The purpose of pilot test is to make sure that the respondent understands the questioner and to find out the shortcomings and ambiguities. The questioner was translated into Arabic to help the respondent to understand it. Ten contractors were asked to fulfill the questionnaire and add any other factor that may cause waste from their point of view. The questionnaire will be reliable when the respondent answers don't include indecisiveness answers. 


\subsection{Research sample}

The research sample should represent the opinion of companies working in infrastructure field. Great care should be taken in choosing the sample to ensure that it represents the actual population. According to the Egyptian Federation of Construction and Building Contractors, the numbers of construction companies working in infrastructure field are as following:

Table (3-2) Number of construction companies in each class in infrastructure field, the Egyptian contractor's federation for construction and building

\begin{tabular}{|c|c|}
\hline Classification & Number of companies \\
\hline First & 65 \\
\hline Second & 36 \\
\hline Third & 56 \\
\hline Fourth & 96 \\
\hline Fifth & 258 \\
\hline Sixth & 197 \\
\hline Seventh & 2648 \\
\hline
\end{tabular}

The following equation was used by (Said Saker, 2006) ${ }^{[10]}$ and many other researches

$$
\mathrm{SS}=\frac{\mathrm{Z} 2 \times(\mathrm{p}) \times(1-\mathrm{p})}{\mathrm{C} 2}
$$

Where:

$\mathrm{SS}=$ Sample size

$\mathrm{Z}=\mathrm{Z}$ value (e.g. 1.96 for $95 \%$ confidence level)

$\mathrm{p}=$ percentage picking a choice, expressed as decimal

(0.5 used for sample size

needed)

$\mathrm{C}=$ confidence interval, expressed as decimal (e.g., 0.05 $= \pm 5$ )

$$
\mathrm{SS}=\frac{(1.96) 2 \times(0.5) \times(1-0.5)}{(0.05) 2}=384
$$

\section{Correction for finite population}

SS

New $\mathrm{SS}=$

$$
\text { SS }
$$

$$
1+\frac{\mathrm{SS}-1}{\text { pop }}
$$

Where:

pop $=$ population

$$
\text { New SS }=\frac{384}{1+\frac{384-1}{3356}}=344.7
$$

To ensure good representation of each stratum, the

following number of each category of certain class has been selected:

First class $=344.7 \times 65 / 3356=7$ contractors
Second class $=344.7 \times 36 / 3356=4$ contractors

Third class $=344.7 \times 56 / 3356=6$ contractors

Forth class $=344.7 \times 96 / 3356=10$ contractors

Fifth class $=344.7 \times 258 / 3356=26$ contractors

Sixth class $=344.7 \times 197 / 3356=20$ contractors

Seventh class $=344.7 \times 2648 / 3356=272$ contractors

The following table shows the result of sample size:

Table no. (3-3) Sample Size

\begin{tabular}{|c|c|c|}
\hline $\begin{array}{c}\text { companies } \\
\text { classification }\end{array}$ & $\begin{array}{c}\text { Number of } \\
\text { companies } \\
\text { (population) }\end{array}$ & $\begin{array}{c}\text { Number of } \\
\text { companies of } \\
\text { sample }\end{array}$ \\
\hline First & 65 & 7 \\
\hline Second & 36 & 4 \\
\hline Third & 56 & 6 \\
\hline Fourth & 96 & 10 \\
\hline Fifth & 258 & 26 \\
\hline Sixth & 197 & 272 \\
\hline Seventh & 2648 & 345 \\
\hline Total & 3356 & 20 \\
\hline
\end{tabular}

For accurate results companies from sixth and seventh class will be excluded because these companies have less experience and efficiency. This study will focus on companies classified as first, second, third and fourth.

In previous studies the researchers faced a problem when many companies refused to fulfill the questioner. (Mohd Fidaus, 2009) ${ }^{[9]}$ reviewed that the respondent percentage was $33 \%$. 40 companies only agreed to answer the questionnaire out of 120 . Some companies don't trust that these data will be used for research purpose only. They fear that these data could be used to impose taxes or something else. This is the result of many years of lack of confidence with the governmental authorities. In this study, the same problem has been faced. Out of 180 questioners, only 51 responded.

\subsection{Data Analysis}

After collecting data, the answers of questionnaire were coded to enable them to be computer processed. The questionnaire is analyzed using statistical package for social science (SPSS). This program provides important data such as mean, median, mode and other statistical methods which are suitable in achieving the objectives of the study. 


\section{4- Result}

\subsection{Company profile and waste strategies}

\subsubsection{Years of experience}

Fig.(4-1) shows the years of experience analysis of the surveyed companies. About $(31.8 \%)$ of the surveyed companies were established in the last five years while the rest have experience more than five years.

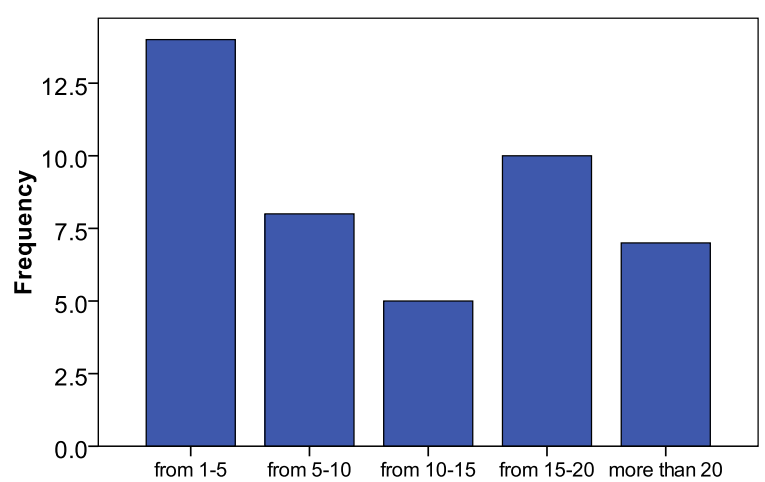

Fig. (4-1) Years of experience

\subsubsection{Respondent position}

Fig.(4-2) shows the respondent position for the surveyed companies. The site engineer has the highest percent $(35.3 \%)$. While projects manager has the lowest percent $(9.8 \%)$.

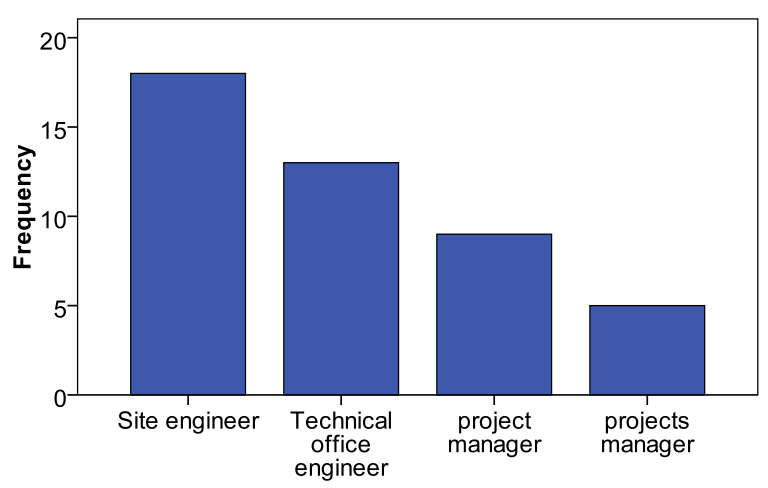

Fig. (4-2) Respondent Position

\subsubsection{Respondent experience}

Fig.(4-3) shows the respondent experience for the surveyed companies. About $(52.9 \%)$ is the percent of respondents have experience form 1-5 years. It also represents the case of the Egyptian construction sector. After the prosperity of construction sector in Arab countries like Saudi Arabia, United Arab Emirates and Arabian gulf in general. That lead to immigration of skilled workers, including engineers, we have a shortage in Egypt in experience between 5 and 20 years.

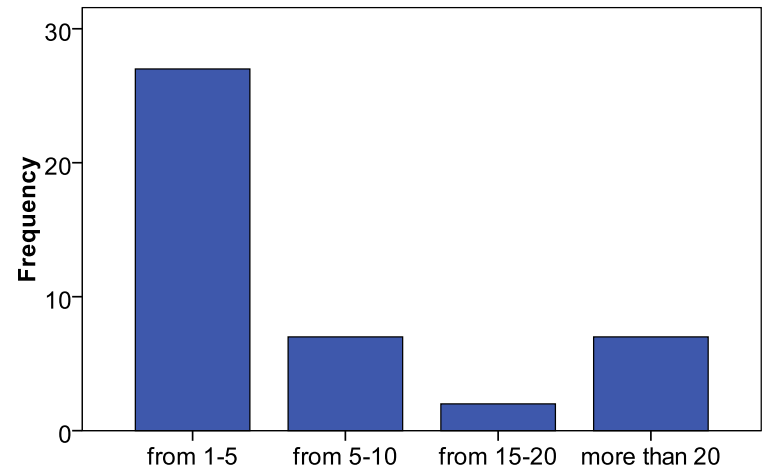

Fig. (4-3) Respondent experience

\subsubsection{Number of projects in last 5 years}

Fig. (4-4) shows the number of projects for the surveyed companies. The category from 5 to 10 years has the highest percent of projects $(35.3 \%)$.

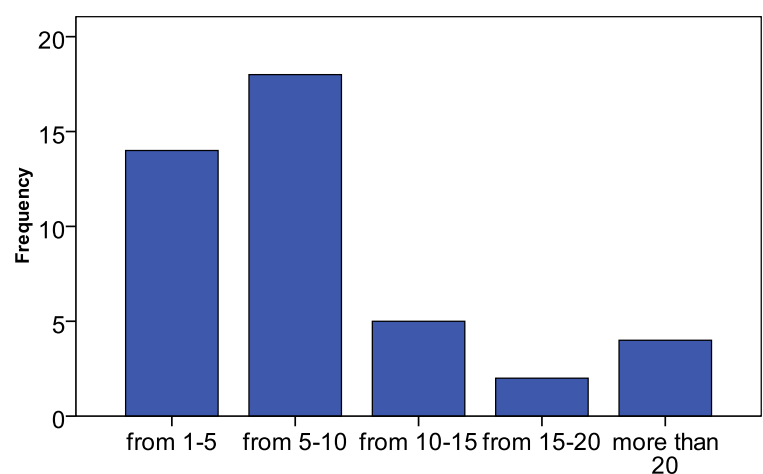

Fig. (4-4) Number of Projects

\subsubsection{Value of projects in last 5 years}

Fig.(4-5) shows the value of projects in the last five years. About (15.7\%) didn't answer this question. The highest percent was $(41.5 \%)$ for projects with value from 1 to 10 millions.

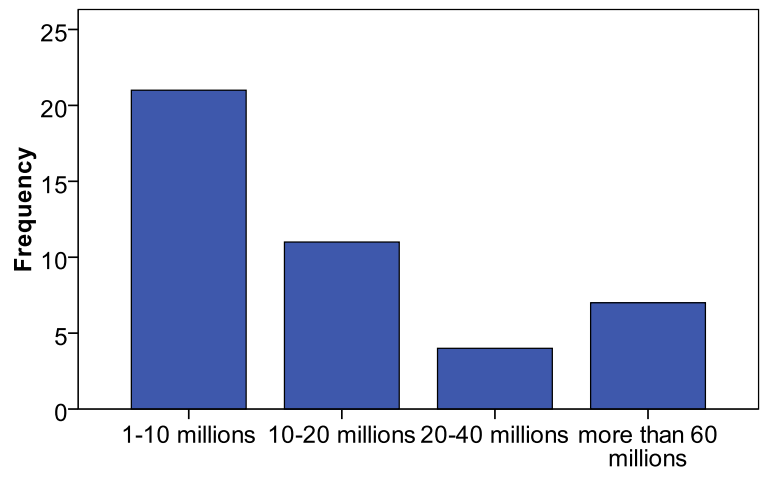

Fig. (4-5) Value of Projects

\subsubsection{Classification of companies}

Fig.(4-6) shows the classification of the surveyed companies. From 180 questionnaires distributed, only 
51 responded. Only 39 respondents answered this question. Many companies were wary of revealing any financial information. About (23.5\%) didn't answer this question. This is a real challenge to most researchers who faced difficult in obtaining financial data as most companies consider it top secret.

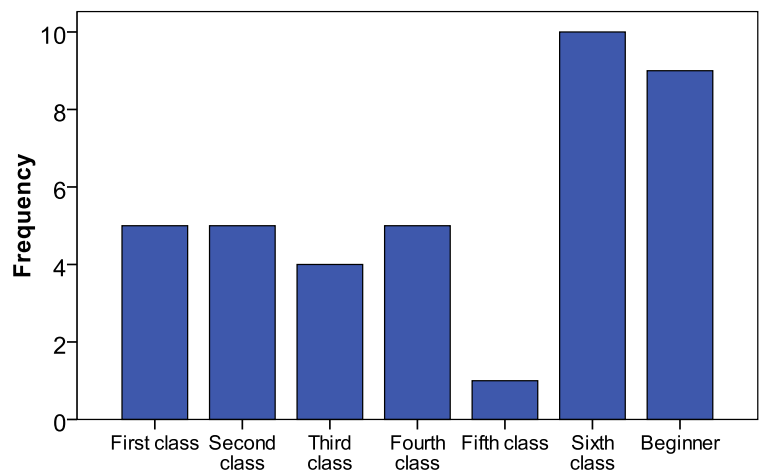

Fig. (4-6) Classification of companies

Table. (4-1) Classification of companies

\begin{tabular}{|c|c|c|c|c|c|}
\hline & & 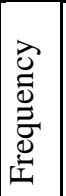 & $\begin{array}{l}\overrightarrow{0} \\
\stackrel{0}{0} \\
\stackrel{0}{0}\end{array}$ & $\begin{array}{l}\overline{0} \\
0 \\
0 \\
0 \\
0 \\
.0 \\
. \bar{J} \\
>\end{array}$ & 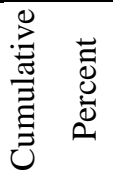 \\
\hline \multirow{8}{*}{ Valid } & $\begin{array}{l}\text { First } \\
\text { class }\end{array}$ & 5 & 9.8 & 12.8 & 12.8 \\
\hline & Second class & 5 & 9.8 & 12.8 & 25.6 \\
\hline & Third class & 4 & 7.8 & 10.3 & 35.9 \\
\hline & Fourth class & 5 & 9.8 & 12.8 & 48.7 \\
\hline & $\begin{array}{l}\text { Fifth } \\
\text { class }\end{array}$ & 1 & 2.0 & 2.6 & 51.3 \\
\hline & Sixth class & 10 & 19.6 & 25.6 & 76.9 \\
\hline & Beginner & 9 & 17.6 & 23.1 & 100.0 \\
\hline & Total & 39 & 76.5 & 100.0 & \\
\hline Missing & System & 12 & 23.5 & & \\
\hline & Total & 51 & 100.0 & & \\
\hline
\end{tabular}

\subsubsection{Plan to control waste}

Fig.(4-7) shows the surveyed companies plan towards waste. Only $(41.2 \%)$ have a strategy to control waste, while $(43.1 \%)$ didn't have any plan.

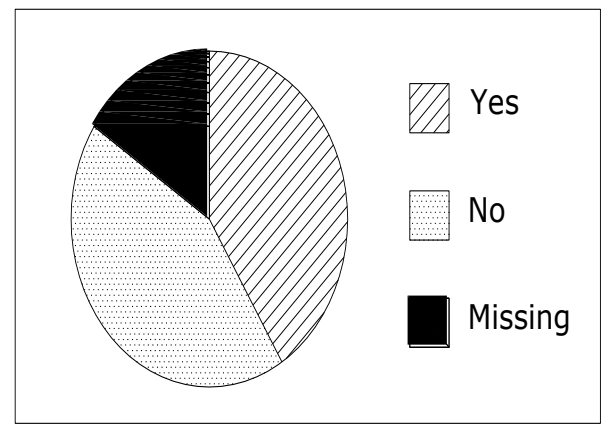

Fig. (4-7) Companies plan to control waste 4.1.8 Training labors

Fig.(4-8) shows the surveyed companies strategy to train labor. Only $(27.5 \%)$ take training labor into consideration, while $(54.9 \%)$ have no strategy for such purpose.

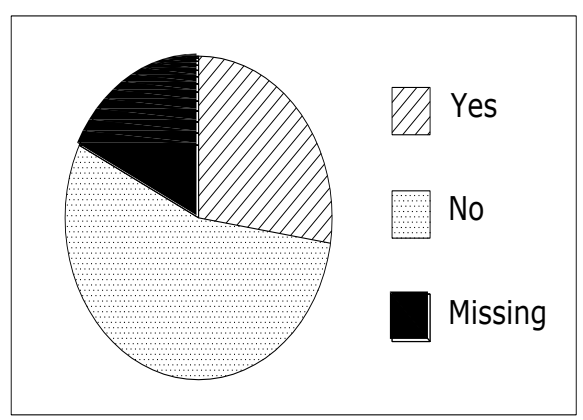

Fig. (4-8) Companies program to train labor

\subsection{Material waste percentage}

An analysis was obtained for 51 questionnaires and the mean was calculated for the following materials. Table (4-1) shows the mean value within the rating scale as below

$$
\begin{aligned}
1 & =\operatorname{range}(0-5) & & (\text { average index }<1.5) \\
2 & =\operatorname{range}(5-10) & & (1.5<\text { average index }<2.5) \\
3 & =\text { range }(10-15) & & (2.5<\text { average index }<3.5) \\
4 & =\text { range }(\text { More than } 15) & & (3.5<\text { average index }<4)
\end{aligned}
$$

Table (4-2) ranges of waste

\begin{tabular}{|c|c|c|}
\hline Materials & Mean & Rang \\
\hline Cement waste & 1.3404 & $0-5$ \\
\hline sand waste & 1.8085 & $5-10$ \\
\hline aggregate waste & 1.7872 & $5-10$ \\
\hline brick waste & 1.933 & $5-10$ \\
\hline Asphalt waste & 1.3077 & $0-5$ \\
\hline Plastic pipe waste & 1.3333 & $0-5$ \\
\hline Cast iron waste & 1.4878 & $0-5$ \\
\hline Precast manholes & 1.2683 & $0-5$ \\
\hline Precast manholes & 1.2195 & $0-5$ \\
\hline Ready mix concrete waste & 1.2727 & $0-5$ \\
\hline Pipe fitting waste & 1.155 & $0-5$ \\
\hline Manholes cover waste & 1.2558 & $0-5$ \\
\hline
\end{tabular}

\subsection{Factors causing waste}

Table (4-2) shows the mean of factor causing waste for the surveyed companies. Design, documentation, equipments, procurement, handling, transportation, 
operation in site, supervision and unexpected condition are all the project phases which were described by 67 question in the questionnaire.

Table no. (4-3) Factors causing waste

\begin{tabular}{|c|c|c|}
\hline No. & Factor & Mean \\
\hline 1 & Designers' low experience & 3.72 \\
\hline 2 & $\begin{array}{l}\text { Lack of awareness of the designer } \\
\text { about the construction procedure }\end{array}$ & 3.96 \\
\hline 3 & $\begin{array}{l}\text { Lack of information about the best } \\
\text { materials types }\end{array}$ & 3.74 \\
\hline No. & Factor & Mean \\
\hline 4 & $\begin{array}{l}\text { Using low price materials with low } \\
\text { quality }\end{array}$ & 3.82 \\
\hline 5 & Design errors & 4.22 \\
\hline 6 & $\begin{array}{l}\text { Inaccurate information from site } \\
\text { investigation }\end{array}$ & 4.20 \\
\hline 7 & $\begin{array}{l}\text { Shortage in dimensions and } \\
\text { specifications on drawings }\end{array}$ & 4.14 \\
\hline 8 & $\begin{array}{l}\text { Designer not aware of what is } \\
\text { available in Egyptian market of } \\
\text { construction materials }\end{array}$ & 3.84 \\
\hline 9 & $\begin{array}{l}\text { Errors in calculating quantities of } \\
\text { contract items }\end{array}$ & 3.46 \\
\hline 10 & $\begin{array}{l}\text { Contract doesn't clarify the } \\
\text { responsibilities of owner and } \\
\text { contractor }\end{array}$ & 4.02 \\
\hline 11 & $\begin{array}{l}\text { Shortage in contract duration and } \\
\text { occurrence of waste because of speed } \\
\text { in construction }\end{array}$ & 3.86 \\
\hline 12 & $\begin{array}{l}\text { Lack of interest in the contract terms } \\
\text { of safety and occupational health }\end{array}$ & 3.80 \\
\hline 13 & $\begin{array}{l}\text { Lack of attention in contract to ways } \\
\text { of resolving disputes }\end{array}$ & 3.76 \\
\hline 14 & Rise in prices of materials & 4.02 \\
\hline 15 & Contractors raise prices in bid prices & 3.82 \\
\hline 16 & Delay in drawings approval & 3.84 \\
\hline 17 & $\begin{array}{l}\text { Delay in construction materials } \\
\text { approval }\end{array}$ & 3.74 \\
\hline 18 & $\begin{array}{l}\text { Making quality control test in } \\
\text { laboratories which are not reliable }\end{array}$ & 3.68 \\
\hline 19 & Errors in contractor bid & 4.04 \\
\hline 20 & Delay of payment to the contractor & 4.10 \\
\hline 21 & Poor schedule & 4.04 \\
\hline 22 & $\begin{array}{l}\text { Slow in obtaining the necessary } \\
\text { permits to start work }\end{array}$ & 3.86 \\
\hline 23 & $\begin{array}{l}\text { Assignment of work to the contractor } \\
\text { with the lowest price without } \\
\text { considering the quality }\end{array}$ & 4.30 \\
\hline 24 & $\begin{array}{l}\text { The poor condition of the company's } \\
\text { equipment }\end{array}$ & 4.06 \\
\hline 25 & High price of rental equipments & 3.96 \\
\hline 26 & High maintenance costs & 3.90 \\
\hline 27 & $\begin{array}{l}\text { Slowdown in the calibration of } \\
\text { sensitive equipment }\end{array}$ & 4.10 \\
\hline 28 & Poor productivity of the equipment & 4.04 \\
\hline
\end{tabular}

\begin{tabular}{|c|c|c|}
\hline & due to the mode of the operator & \\
\hline 29 & $\begin{array}{l}\text { Using of equipments not mentioned it } \\
\text { the contract }\end{array}$ & 3.90 \\
\hline 30 & Fuel high prices & 3.88 \\
\hline 31 & $\begin{array}{l}\text { Damaged pipes and cables duo to } \\
\text { lack of a good map for infrastructure }\end{array}$ & 4.21 \\
\hline 32 & $\begin{array}{l}\text { Purchase from the supplier who has } \\
\text { lowest price regardless of quality }\end{array}$ & 3.92 \\
\hline 33 & $\begin{array}{l}\text { Purchase materials do not confirm to } \\
\text { contract specifications }\end{array}$ & 4.02 \\
\hline 34 & $\begin{array}{l}\text { Buy from a supplier which is not } \\
\text { reliable by the owner }\end{array}$ & 4.04 \\
\hline No. & \begin{tabular}{|l} 
Factor \\
\end{tabular} & Mean \\
\hline 35 & $\begin{array}{l}\text { Purchase of materials greater or less } \\
\text { than the required }\end{array}$ & 4.02 \\
\hline 36 & $\begin{array}{l}\text { Lack of good description of the } \\
\text { required materials in purchase order }\end{array}$ & 4.17 \\
\hline 37 & Making schedule for supplies & 4.04 \\
\hline 38 & $\begin{array}{l}\text { Delay caused by modification in } \\
\text { purchase order }\end{array}$ & 3.75 \\
\hline 39 & $\begin{array}{l}\text { Lack of attention to examine the } \\
\text { materials when supplied }\end{array}$ & 4.10 \\
\hline 40 & $\begin{array}{l}\text { The inability of supplying small } \\
\text { quantities }\end{array}$ & 4.13 \\
\hline 41 & $\begin{array}{l}\text { Using wrong way in handing each } \\
\text { materials }\end{array}$ & 3.98 \\
\hline 42 & $\begin{array}{l}\text { Lack of attention to safety procedure } \\
\text { and occupational health }\end{array}$ & 3.96 \\
\hline 43 & Road accidents & 3.74 \\
\hline 44 & $\begin{array}{l}\text { Long distance between project and } \\
\text { supplier }\end{array}$ & 4.15 \\
\hline 45 & $\begin{array}{l}\text { Overloading the truck with material } \\
\text { or using wrong way in loading }\end{array}$ & 4.02 \\
\hline 46 & $\begin{array}{l}\text { Arrangement of the stoke and } \\
\text { separation of each kind of materials }\end{array}$ & 4.00 \\
\hline 47 & Using wrong way in storing materials & 4.13 \\
\hline 48 & Storage protection & 4.13 \\
\hline 49 & $\begin{array}{l}\text { Making database on the quantities } \\
\text { used and remained in the stoke and } \\
\text { remained materials in purchase order }\end{array}$ & 4.15 \\
\hline 50 & Cutting materials in wrong way & 4.08 \\
\hline 51 & Lack of harmony between teamwork & 4.02 \\
\hline 52 & $\begin{array}{l}\text { Lack of motivation of labors duo to } \\
\text { low salaries }\end{array}$ & 4.19 \\
\hline 53 & Lack of manpower & 4.22 \\
\hline 54 & Lack of experience of site engineer & 4.20 \\
\hline 55 & Low technical level of labors & 4.33 \\
\hline 56 & $\begin{array}{l}\text { Low experience of project manager in } \\
\text { managing the work }\end{array}$ & 4.33 \\
\hline 57 & $\begin{array}{l}\text { Delay in taking decision by the } \\
\text { project manager }\end{array}$ & 4.48 \\
\hline 58 & Poor planning of project layout & 4.33 \\
\hline 59 & Acceptance of defected work & 3.86 \\
\hline 60 & $\begin{array}{l}\text { Low experience of the supervisor } \\
\text { engineer }\end{array}$ & 4.12 \\
\hline
\end{tabular}




\begin{tabular}{|c|l|c|}
\hline 61 & $\begin{array}{l}\text { Lack of supervision by the supervisor } \\
\text { engineer }\end{array}$ & 4.24 \\
\hline 62 & Low number of supervisors & 4.22 \\
\hline 63 & $\begin{array}{l}\text { Slow in taking decision by the } \\
\text { supervisor }\end{array}$ & 4.27 \\
\hline 64 & $\begin{array}{l}\text { Bad relation between owner and } \\
\text { supervisor and contractor }\end{array}$ & 4.10 \\
\hline 65 & Bad weather conditions & 3.85 \\
\hline 66 & Strike actions and demonstrations & 3.92 \\
\hline 67 & $\begin{array}{l}\text { Disruption of water and electricity } \\
\text { supply }\end{array}$ & 3.94 \\
\hline
\end{tabular}

\section{PROPOSED PROJECT MODEL}

This study is aiming to develop a tool to predict the percent of waste for the most common materials in infrastructure projects. Previous studies showed that each material has a very wide rang of performance (Said Saker, 2006) ${ }^{[10]}$. So, this software is developed for infrastructure projects only. CCCW "Computer Checklist for Calculating Waste" is the name of this developed software.

\subsection{Procedure of project model}

Based on data analysis, this program goes through four steps to predict value of waste:

1- Estimation of waste factors weights; This study considers two ways for this objective. The first way used the mean value of waste factors from the survey analysis to estimate the weight of each factor. Then, a checklist is developed including 99 questions.

Table (5-1) shows some question of design stage. This method considered the percent of mean as a weight.

Table (5-1) weights of first method

\begin{tabular}{|l|l|c|}
\hline Code & Questions to consider & Weight \\
\hline 1.1 .1 & $\begin{array}{l}\text { Is the designer has the required } \\
\text { experience in design of } \\
\text { infrastructure }\end{array}$ & 1.38 \\
\hline 1.2 .1 & $\begin{array}{l}\text { Is the designer aware about the } \\
\text { construction procedure }\end{array}$ & 0.74 \\
\hline 1.2 .2 & $\begin{array}{l}\text { Is there coordination between the } \\
\text { designer and site engineer during } \\
\text { design }\end{array}$ & 0.74 \\
\hline 1.3 .1 & $\begin{array}{l}\text { Should the designer know required } \\
\text { kinds of materials }\end{array}$ & 1.39 \\
\hline 1.4 .1 & $\begin{array}{l}\text { Will the designer choose high } \\
\text { quality materials regardless cost }\end{array}$ & 1.42 \\
\hline 1.5 .1 & $\begin{array}{l}\text { Is there enough consideration } \\
\text { given for site investigation }\end{array}$ & 0.78 \\
\hline 1.5 .2 & $\begin{array}{l}\text { shouldn't the designer depend on } \\
\text { these data taken from a near project }\end{array}$ & 0.78 \\
\hline 1.6 .1 & $\begin{array}{l}\text { Is there a person responsible for } \\
\text { revising design with drawings }\end{array}$ & 0.78 \\
\hline 1.6 .2 & \begin{tabular}{l} 
Is the designer keen to check the \\
\hline
\end{tabular} & 0.78 \\
\hline
\end{tabular}

\begin{tabular}{|c|l|c|}
\hline & $\begin{array}{l}\text { output data from computer design } \\
\text { programs }\end{array}$ & \\
\hline 1.7 .1 & $\begin{array}{l}\text { Are all dimensions illustrated on } \\
\text { the drawing clearly }\end{array}$ & 0.77 \\
\hline 1.7 .2 & Are all materials well specified & 0.77 \\
\hline 1.8 .1 & $\begin{array}{l}\text { Is the designer familiar with } \\
\text { materials available locally }\end{array}$ & 1.43 \\
\hline
\end{tabular}

The second way use person correlation coefficient to find the relation between waste factors and waste in construction materials. Then, all these relations which have negative relations or significance $<=.05$ have been executed. Finally, the accepted relations have been used to find the weights of each factor.

Table (5-2) shows some question of design stage. This method considered the percent of each relation as a weight.

Table (5-2) weights of second method

\begin{tabular}{|c|c|c|c|c|c|c|c|c|c|c|c|c|}
\hline 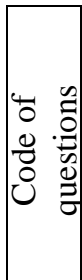 & 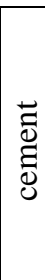 & & $\left|\begin{array}{l|}0 \\
\widetilde{0} \\
60 \\
0 \\
0 \\
00 \\
\sigma \\
\sigma\end{array}\right|$ & $\frac{4}{\breve{g}}$ & $\left|\begin{array}{l}\frac{2}{\pi} \\
\frac{2}{2} \\
\frac{2}{2}\end{array}\right|$ & 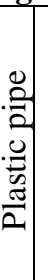 & 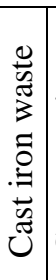 & $\begin{array}{l}u \\
0 \\
. \\
0 \\
0 \\
0 \\
0 \\
0 \\
0 \\
0\end{array}$ & 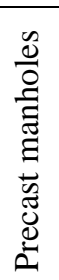 & 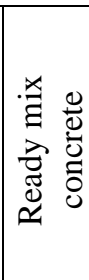 & 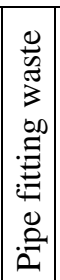 & 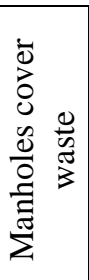 \\
\hline$\rightrightarrows$ & 0 & $\stackrel{\infty}{\stackrel{\infty}{m}}$ & 0 & 0 & $\frac{m}{0}$ & ఫ్ర & $\stackrel{m}{i}$ & 0 & $\begin{array}{l}\stackrel{8}{\circ} \\
\dot{+}\end{array}$ & $\begin{array}{l}\infty \\
\stackrel{\infty}{0} \\
\text {. }\end{array}$ & $\stackrel{\vec{\sigma}}{-}$ & 0 \\
\hline$\stackrel{\vec{c}}{\rightarrow}$ & 0 & 0 & 0 & 0 & 0 & 0 & $\bar{a}$ & 0 & $\stackrel{\text { I }}{0}$ & $\stackrel{\varrho}{\rightleftarrows}$ & 0 & 0 \\
\hline 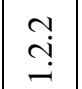 & 0 & 0 & 0 & 0 & 0 & 0 & $\overline{\hat{\sigma}}$ & 0 & $\stackrel{\mathscr{T}}{\circ}$ & $\stackrel{?}{=}$ & 0 & 0 \\
\hline$\ddot{n}$ & 0 & 0 & 0 & 0 & $\mid \begin{array}{c}0 \\
\infty \\
i\end{array}$ & $\begin{array}{c}\infty \\
\stackrel{\infty}{0} \\
\end{array}$ & $\begin{array}{l}\tilde{\sigma} \\
\hat{i}\end{array}$ & 0 & $\underset{-\sigma}{\sigma}$ & $\vec{\sigma}$ & $\begin{array}{l}n \\
0 \\
r\end{array}$ & 0 \\
\hline$\underset{+}{\stackrel{+}{+}}$ & 0 & 0 & 0 & 0 & 0 & 0 & 0 & $\begin{array}{l}\dot{J} \\
\dot{\forall}\end{array}$ & 0 & 0 & 0 & $\stackrel{0}{0}$ \\
\hline$\vec{n}$ & 0 & 0 & 0 & 0 & $\left|\begin{array}{c}\infty \\
\infty \\
0\end{array}\right|$ & חొ? & $\frac{\partial}{\vec{i}}$ & 0 & $\overrightarrow{\tilde{o}}$ & 0 & 0 & 0 \\
\hline$\stackrel{n}{\dddot{n}}$ & 0 & 0 & 0 & 0 & $\mid$ & 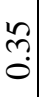 & $\stackrel{\vec{i}}{\vec{i}}$ & 0 & $\overrightarrow{\widetilde{o}}$ & 0 & 0 & 0 \\
\hline تِّ & 0 & 0 & 0 & 0 & 0 & 0 & 0 & 0 & 0 & $\bar{m}$ & 0 & 0 \\
\hline 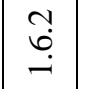 & 0 & 0 & 0 & 0 & 0 & 0 & 0 & 0 & 0 & $\bar{m}$ & 0 & 0 \\
\hline$\stackrel{\square}{\check{r}}$ & 0 & 0 & 0 & 0 & 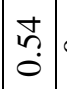 & 0 & $\begin{array}{l}\mathbb{U} \\
\dot{0}\end{array}$ & 0 & $\stackrel{\hat{\imath}}{i}$ & $\begin{array}{l}\infty \\
0 \\
0\end{array}$ & $\underset{\substack{q \\
i}}{ }$ & 0 \\
\hline 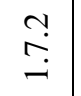 & 0 & 0 & 0 & 0 & ?ִ & 0 & $\begin{array}{l}\mathbb{t} \\
\stackrel{0}{0}\end{array}$ & 0 & $\stackrel{i}{i}$ & $\begin{array}{l}\infty \\
0 \\
0\end{array}$ & $\underset{i}{\stackrel{q}{i}}$ & 0 \\
\hline$\vec{\infty}$ & 0 & 0 & 0 & 0 & $\begin{array}{l}\stackrel{n}{f} \\
\dot{m}\end{array}$ & 0 & 0 & 0 & 0 & $\hat{n}$ & $\begin{array}{l}\tilde{\sigma} \\
i\end{array}$ & 0 \\
\hline
\end{tabular}


1- Ranges of constructions materials waste;

Table (5-3) material waste range

\begin{tabular}{|r|c|l|}
\hline Class & $\begin{array}{c}\text { Range of } \\
\text { waste }\end{array}$ & \multicolumn{1}{|c|}{ Materials } \\
\hline $\begin{array}{r}\text { First } \\
\text { (W1) }\end{array}$ & $(5-10) \%$ & Sand, Aggregate and Brick \\
\hline $\begin{array}{c}\text { Second } \\
\text { (W2) }\end{array}$ & $(0-5) \%$ & $\begin{array}{l}\text { Cement, Asphalt, Plastic } \\
\text { pipes, Cast iron pipes, } \\
\text { Concrete pipes, Pre-cast } \\
\text { manholes, Ready mix } \\
\text { concrete, Pipe fittings and } \\
\text { manholes covers }\end{array}$ \\
\hline
\end{tabular}

\section{2- Efficiency of controlling waste;}

After the user inputs the prices and quantities of project materials, he goes to the second part of the checklist which consists of 99 "yes or no" questions. When the user check "no", he losses the percent or weight of this questions. Finally, the software cumulates the weight of questions answered by "no". Efficiency of controlling waste could be estimated by subtracting the cumulative negative questions from $100 \%$.

\section{3- Probable waste value;}

In order to find the probable waste value, this thesis produces two methods. The first method is obtained by using the E-W chart. By finding the efficiency of controlling waste (E) as illustrated before, the user could enter this chart and get the value of W1 \& W2 which represents the probable waste percentage for these materials shown in the previous table.

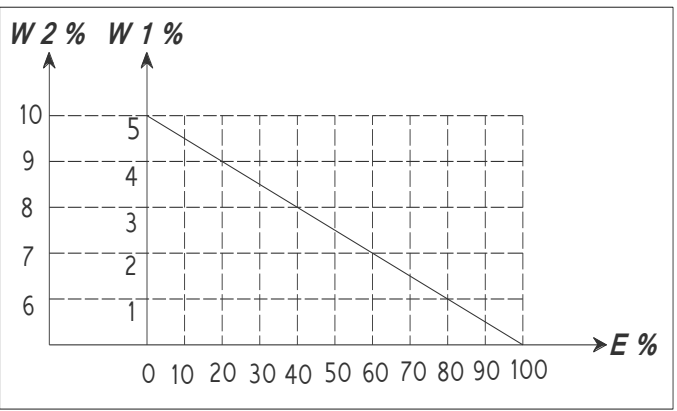

Fig. (5-1) Finding probable waste percentage using E-W chart

Where: E\%: Efficiency of Controlling Waste W1\%: Probable Waste Percentage from 0\% to $5 \%$ for first class materials W2\%: Probable Waste Percentage from 5\% to $10 \%$ for second class material

For example; if the efficiency of controlling waste equals $50 \%$, the probable waste value for first class materials (W1) will be equal to $2.5 \%$ and the value for second class materials (W2) will be equal to $7.5 \%$ as shown in the following chart.

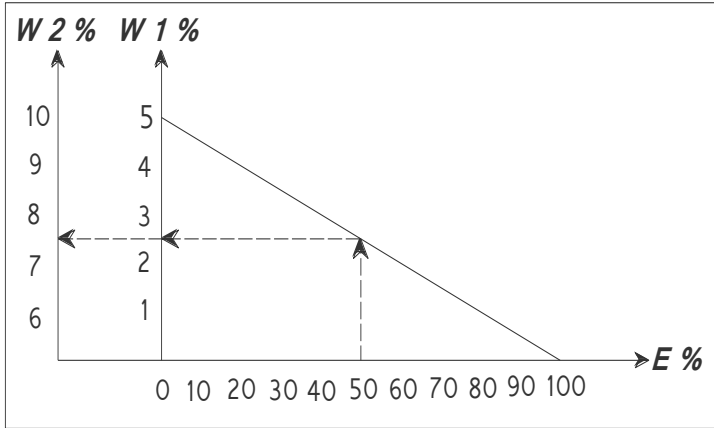

Fig. (5-2) How to use E-W chart

The second method is obtained by using equation. The following two equations are used for the same purpose.

$\mathrm{W} 1=5-\mathrm{E} \times .05$

$\mathrm{W} 2=10-\mathrm{E} \times .05$

Where $\mathrm{W} 1, \mathrm{~W} 2$ and $\mathrm{E}$ as mentioned before

\section{4- Final results}

There are two outputs of CCCW. First output is probable waste values. The waste value could be calculated by using the following equation:

\section{(Quantities) $\quad x$ (Price) $\quad x \quad$ (Probable waste percentage $)=($ Probable waste value $)$}

The second output that the user could minimize losses to the optimum waste value through commitment to advices offered by the software. The minimum waste percent is calculated using the following equation

\section{(Quantities) $\quad x \quad$ (Price) $\quad x \quad$ (Minimum waste} percentage $)=($ Minimum waste value $)$

\subsection{Using CCCW program}

The software consists of three sections. In the first section, the user input price an d quantities of project as shown in fig.no.(5-3). In the second section, the user answers 99 questions which describe all project aspects as shown in fig.no.(5-4). In the last section, the user could get the probable waste value in each kind of materials as shown in fig. no.(5-5).

\begin{tabular}{|c|c|l|l|}
\hline & Units & Quantities & Price \\
\hline Cement & Tons & & \\
\hline Sand & $\mathrm{m} 3$ & & \\
\hline Aggregate & $\mathrm{m} 3$ & & \\
\hline Brick & $\mathrm{m} 3$ & & \\
\hline Asphalt & $\mathrm{m} 2$ & & \\
\hline Plastic pipes & $\mathrm{M}$ & & \\
\hline Cast iron pipes & $\mathrm{M}$ & & \\
\hline Concrete Pipes & $\mathrm{M}$ & & \\
\hline Pre-cast manholes & Number & & \\
\hline Ready mix concrete & $\mathrm{m} 3$ & & \\
\hline Pipe fitting & Number & & \\
\hline Manholes covers & Number & & \\
\hline
\end{tabular}


fig. no. (5-3) price\& quantities

\begin{tabular}{|l|c|}
\hline \multicolumn{1}{|c|}{ Questions } & $\begin{array}{c}\text { Answer } \\
\text { is NO }\end{array}$ \\
\hline Is the designer aware about the construction procedure & \\
\hline $\begin{array}{l}\text { Is there coordination between the designer and site engineer } \\
\text { during design }\end{array}$ & \\
\hline Should the designer know required kinds of materials & \\
\hline $\begin{array}{l}\text { Will the designer choose high quality materials regardless } \\
\text { cost }\end{array}$ & \\
\hline Is there enough consideration given for site investigation & \\
\hline $\begin{array}{l}\text { shouldn't the designer depend on these data taken from a } \\
\text { near project }\end{array}$ & \\
\hline $\begin{array}{l}\text { Is there a person responsible for revising design with } \\
\text { drawings }\end{array}$ & \\
\hline $\begin{array}{l}\text { Is the designer keen to check the output data from computer } \\
\text { design programs }\end{array}$ & \\
\hline
\end{tabular}

fig.(5-4) checklist

\begin{tabular}{|c|c|c|c|}
\hline & Units & $\begin{array}{c}\text { Probable waste } \\
\text { percent }\end{array}$ & Price \\
\hline Cement & Tons & & \\
\hline Sand & $\mathrm{m} 3$ & & \\
\hline Aggregate & $\mathrm{m} 3$ & & \\
\hline Brick & $\mathrm{m} 3$ & & \\
\hline Asphalt & $\mathrm{m} 2$ & & \\
\hline Plastic pipes & $\mathrm{M}$ & & \\
\hline Cast iron pipes & $\mathrm{M}$ & & \\
\hline Concrete Pipes & $\mathrm{M}$ & & \\
\hline Pre-cast manholes & Number & & \\
\hline Ready mix concrete & $\mathrm{m} 3$ & & \\
\hline \multicolumn{2}{|c|}{ Pipe fitting } & Number & \\
\hline Manholes covers & Number & & \\
\hline
\end{tabular}

\subsection{Case Studies}

This program is studied for applicability using several miscellaneous case studies. The actual percent of waste was calculated in 6 projects for different materials. Then, these projects conditions were applied to $\mathrm{CCCW}$ program to predict the percent of waste.

The purpose of this section is to confirm correct application of two important items. The first item is to make sure that the values of waste in site are coinciding to what has been determined by the surveyed companies. For example, the quantity of sand waste is ranging from $5 \%$ to $10 \%$ according to the survey analysis. This section will try to find a way to determine the value of waste for the sand in site and compare it with the results of the survey. The second item, checking the correct application of the program and make sure that the results from project is close to the values of waste at site.

Determination of the value of waste in site is very difficult for two main reasons. The first reason is that contractors wary of revealing any financial information. The second reason is that most of contractors do not have a complete data base on quantities of materials to be implemented or purchased or values of waste for all project items. So, this section will focus on the main items of infrastructure project such as pipe lines.

The following cases calculate the waste by same way mentioned later. In each case there is a store in the project. The contractor receives the required material he needs form the store. At the end of every month the contractor will be paid according to what he has implemented and installed materials. So, the waste value will be the difference between what the contractor received and what he has implemented. The first three cases discussed waste in plastic pipes and the last three cases discussed waste in cement.

Table (5-1) shows the actual percent of waste in site and probable waste percent developed from CCCW for the same cases. The results show that the maximum difference is $2.28 \%$ after exclusion of the results of the fourth case. The main cause of inaccurate results obtained in the fourth case was becau

se the ready mix concrete was delivered to site less than requested. When checking the volume of concrete in truck mixer it was found less than mentioned in the request policy with the truck mixer deriver. This may be due to an error in the mixer or may be illegal behavior by those responsible for the mixer.

Table (5-4) testing results

\begin{tabular}{|l|c|c|c|}
\hline & $\begin{array}{c}\text { Actual percent } \\
\text { of waste \% }\end{array}$ & $\begin{array}{c}\text { Probable } \\
\text { percent of } \\
\text { waste } \%\end{array}$ & Diff. \\
\hline Case (1) & 3.18 & 2.61 & -0.57 \\
\hline Case (2) & 1.49 & 2.11 & 0.62 \\
\hline Case (3) & 4.78 & 2.5 & -2.28 \\
\hline Case (4) & 7.05 & 3.51 & -3.54 \\
\hline Case (5) & 2.08 & 2.74 & 0.66 \\
\hline Case (6) & 4.99 & 3.55 & -1.44 \\
\hline
\end{tabular}

The correlation value between actual and probable waste percent is (.784).

\section{DISCUSSION AND CONCLUSION}

Table (6-1) shows the rank of the main factors causing waste in infrastructure in Egypt.

The factor that has got the highest rank in this thesis was project manager ability to take right decisions in the right time with average index of 4.48 . This result is compatible with the findings of many researches as the project manager is the key for any project success. There should be an evaluation for the candidates for the project manager position. 
Table (6-1) Rank of the main factors causing waste

\begin{tabular}{|c|c|c|}
\hline No. & Factor & Mean \\
\hline 57 & $\begin{array}{l}\text { Delay in taking decision by the } \\
\text { project manager }\end{array}$ & 4.48 \\
\hline 55 & Low technical level of labors & 4.33 \\
\hline 56 & $\begin{array}{l}\text { Low experience of project manager } \\
\text { in managing the work }\end{array}$ & 4.33 \\
\hline 58 & Poor planning of project layout & 4.33 \\
\hline 23 & $\begin{array}{l}\text { Assignment of work to the } \\
\text { contractor with the lowest price } \\
\text { without considering the quality }\end{array}$ & 4.3 \\
\hline 63 & $\begin{array}{l}\text { Slow in taking decision by the } \\
\text { supervisor }\end{array}$ & 4.27 \\
\hline 61 & $\begin{array}{l}\text { Lack of supervision by the } \\
\text { supervisor engineer }\end{array}$ & 4.24 \\
\hline
\end{tabular}

Low technical level of labor was chosen by the respondents as the second causing waste factor with an average index of 4.33. Uneconomical cutting of materials by untrained labor consumes huge amounts of raw materials. Training courses should be performed to raise there technique level. This thesis shows that only $27.5 \%$ of investigated companies have a plan to train labor. If certifications showing technical level of labor must be submitted as one of any tender documents that will encourage construction companies to train there labor.

The following factor is more related to human management. The managerial capabilities of project manager was chosen by the respondent as the third factor. Many waste losses occur not only because of the technical level of project manager but also because of his managerial capabilities as well. Motivation of workers and keeping good relation with all project team parties is one of the main objectives of project leader. It is very useful to give project managers the required courses to improve their skills in human management.

Another important factor need to be given the required concern was poor design of project layout. Some notes should be taken into consideration while design the layout. Temporary road should coincide with the permanent road. Storage areas and labor housing should be away from the required work location to avoid need to move such facilities. Prevailing wind direction should be taken into consideration while detecting the position of workers housing, bathrooms and welding workshop.

Assigning of the work to contractor with the lowest bid regardless of the quality is a very important factor. It was chosen by the respondents as the fifth factor with an average index of 4.30. Quality and waste control should be taken into consideration beside price before assigning the work to any contactor. A detailed plan for controlling waste should be submitted with tender documents. This thesis shows that $43.1 \%$ of companies working in the infrastructure field didn't have any plan for waste reduction.

The following two factors associated with supervision. Being slow in taking decision by consultants was chosen by respondents with an average index 4.27. Lack of supervision by consultant or site engineer has a great effect on waste occurrence. It was chosen by respondents with an average index 4.24.

\section{REFERENCE}

[1] Yahya, K., Boussabaine, A.H., 2006. Eco-costing of construction waste. Management of Environmental Quality: An International Journal, Vol. 17 No. 1, pp. 6-19.

[2] CRISTIANO R. CASTELO BRANCO, 2007, AN EFFECTIVE WAY TO REDUCE RESIDENTIAL CONSTRUCTION, Master of science, Texas A\&M University, USA

[3] Ekanayake, L.L, Ofori, G., 2004. Building waste assessment score: design-based tool. Building and Environment 39, 851-861.

[4] Rohit Bhagwat, 2008, Site Waste Management Practices in Construction Industry in United Kingdom, A dissertation submitted to The University of Manchester for the degree of Master of Science in Environmental Sciences, Policy, and Management jointly operated by the university of Aegean (Greece)

[5] Pinto,T. P., and Agopayan, V. 1994, "Construction wastes as raw materials for low -cost construction products." Sustainable construction (Proc. 1st Conf. Of CIB TG 16), J.Kibert,ed., Ctr. For Constr. and Envir., Gainesville, Fla., 335-342.

[6] Hamassaki, L.T., Neto, C.S., 1994. Technical and econo pects of construction / demolition waste utilization. Sustainable structure (proc. 1st conf of CIB TG 16), construction and environment, Gainesville Fla., 395-403.

[7] Formoso, C.T. Franchi, C., Soibelman, L., 1994. "A study on the waste of materials in the building industry in Brazil." Sustainable construction ( Proc. 1 st Conf. of CIB TG 16) C.J.Kibert, ed., Ctr. For Constr. And Envir., Gainesville, Fla., 555-563.

[8] Wong Xiao Wen, 2007, Waste Minimization By Recycling Of Construction Waste, Master of science, University of technology, Malaysia

[9] Mohd Fidaus Bin Mustaffa Kamal,2009, Reduce, Reuse, Recycle and Recovery technique in sustainable construction waste management, Master of science, University of technology, Malaysia

[10] Said Saker Al-Moghany, February, 2006, Managing and Minimizing Construction Waste in Gaza Strip, Master of science, The Islamic University of Gaza Palestine. 